\title{
Progress at NERC
}

SIR - As the new chairman of the Natural Environment Research Council (NERC), and after 8 years as a council member, I was intrigued to read your article (Nature 11 October, p.498) on the British Geological Survey and the related leading article (p.493) advocating the disbandment of the council.

While you have correctly identified some of the problems with which the council has grappled in recent years, I am disappointed that you have not recognized more fully the progress the council has made in the context of a severe shortage of funds.

The objective of a research council is to foster high-quality science in institutes and universities. Achieving this requires, firstly, well-motivated scientists and support staff, and secondly, money to pay them and supply the necessary support services and equipment. In spite of the council's strenuous efforts to persuade the government that environmental sciences need and deserve more funds, these have not been forthcoming on the science vote. Indeed, in the areas of NERC interest, with the exception of Antarctic research, science vote money has shrunk in recent years. Equally significant is the substantial reduction of income from commissioned research sponsored by government departments.

In the face of these reductions, my council has been at pains to maintain the level of its support for university research and has attempted to find new sources of commissioned research funds with the private sector. Contrary to your editorial comments, this has been done in line with principles clearly laid down by the Treasury, is largely on a collaborative rather than a competitive basis and is leading to the successful transfer of knowledge and technology from basic research to industry.

It will not surprise you or your readers that I reject your proposed solution to NERC's present difficulties and believe it would benefit neither science nor the country. It is a solution we have already examined and dismissed because we believe there is a real need within the United Kingdom for an organization which can promote objective environmental research to provide a basis for sound industrial, economic and political policies.

In taking up the office of chairman of NERC, I intend to continue actively the programme of reorganization and structural change which is already in hand and which, I believe, will provide purposeful support for environmental science research - basic, strategic and applied - of benefit to industry and government.

I trust that you and your readers will continue to show interest in the development of NERC and be prepared to recognize achievements resulting from reorganization as it proceeds. I believe that NERC has a strong and vibrant contribution to offer the United Kingdom and the scientific community and that the environmental sciences deserves more than the emasculation you propose.

HUGH FISH

Natural Environment Research Council, Polaris House, North Star Avenue, Swindon SN2 IEU, UK

\section{Telling all}

SIR - In his article "Widespread aftereffects of nuclear war"' (Nature 23 August, p. 621), Dr Edward Teller points out that we should not expose the general public to highly speculative theories of worldwide destruction. Instead we should tell people exactly what we know and do not know about the nuclear winter, "for only then can decisions affecting the well-being of Western societies be made on an intelligent basis". I think that the general public would be even more satisfied if the decisions could consider the well-being of all societies.

Department of Zoology,

University of Helsinki,

00100 Helsir.ki, Finland

\section{US deficit}

SIR - Your leading article "Election irrelevant" (13 September, p.92) wonders about the arithmetic of funding the US federal budgetary deficit.

In the fiscal year ending 30 September, this will be $\$ 172,000$ million $^{1}$, but the trade deficit this year may exceed $\$ 130,000$ million $^{2}$. The dollars expatriated on current account are therefore sufficient to cover $130 / 172$ or 75 per cent of the budgetary shortfall if reinvested on capital account directly or indirectly in American government securities.

3305 Pottawattamie Trail,

BRIAN POTTER

Michigan City, Indiana 46360, USA

1. The Economist, 15 September, 1984, p.24 2. Ibid, p.18.

\section{Miracles}

SIR - Berry et al. (see Nature, 19 July, p.171) must be born-again Baconians. This conclusion can be drawn from their statement that the laws of science are generalizations of experience and therefore cannot be applied to the examination of claims for miracles. Falsificationists would define the accumulations of scientific laws in terms of hypotheses that have so far survived empirical testing.

This subtle difference in emphasis suggests that the debunking of miracles is a job for a falsificationist whereas a neoBaconian may be permitted the luxury of faith without being faced by a dilemma. It is however interesting to note that in fact professional illusionists appear to be better investigators of miracles than scientists, if the Yuri Geller investigation can be regarded as an exemplar of a rational examination of a claim for supernatural powers.

Berry et al. may therefore have arrived at a correct conclusion but for the wrong reasons. Alternatively, professional magicians perhaps may be regarded as conducting scientific research in the Popperian tradition when employed in the investigation of miracles.

BARRIE PEARSON

13 Knoll Cottage

Residential Park,

Winfrith, Dorchester,

Dorset DT2 8LD, UK.

\section{Enough of Homer}

SIR - M. Pulbrook (Nature 309, 204; 1984), focusing on a parenthetic point I made within a quote-marked hypothetical question (Nature 307, 590; 1984), has produced an interesting exegesis on black versus red Homeric wine - but the contrast I had in mind was red/white, or yellow. Compare the classicist W.B. Stanford, Commentary on Odyssey, 1947, Vol. 1, p. 355 , line 196, Bk. IX: Homer "never mentions white or yellow wines". And pace Pulbrook, I did not assume that the key question in the wine-dark sea controversy is to "account for the redness of the sea": this surely is evident from my mention of many other aspects of the topic, formulaic devices, for example.

As the distant Homeric world-view and pattern of sensibility differ significantly from ours, our thinking about Homer's epics is easily subject to various colourations. And whatever the pros and cons of translating oivon $\alpha$ noviov as "winedark sea", the English phrase itself is viable and poetically very potent: to exemplify a facet, Kazantzakis once envied the relative monosyllabicality (!) of English.

This interdisciplinary international correspondence has been piquant. Floreat Nature . . .

\section{Philosophy Department,} University of South Africa, PO Box 392,

\section{Pretoria 0001, South Africa}

SIR - Regarding your editorial note about this correspondence (Nature 12 July, p.95), the literati used to believe that the last word came from Stephen Dedalus when he spoke the winged words "snotgreen and scrotumtightening sea" (Joyce, J. Ulysses, Bodley Head, London, 1937).

Thank you nevertheless for your nostalgic revival of a dying culture, so aptly rounded by a scholarly note from Balliol.

HILTON STOWELl

\section{ERBP Laboratory,}

120 Nature Creek $S W$,

Milledgeville, Georgia 31061, USA

- This correspondence is now closed Editor, Nature. 